\title{
An immunofluorescence method for the diagnosis of primary syphilis using an absorption technique
}

\author{
M. F. GARNER AND J. H. ROBSON \\ From the Institute of Clinical Pathology and Medical Research, Department of Public Health, \\ Sydney, Australia
}

SYNOPSIS An immunofluorescence technique for demonstrating Treponema pallidum in fixed films made from suspected chancre exudate is described. The method used is basically a reversal of the्ध fluorescent treponemal antibody absorption test. It makes use of the fact that by using a syphilition serum from which group antibody has been absorbed by an extract of Reiter treponemes, leaving only specific antibody, Treponema pallidum can be indentified. Neither the non-pathogenic genitaL treponemes nor mouth treponemes showed any fluorescence when tested by the technique described $\infty$

All the reagents used in the test are available commercially, thus placing it within the scope of any? laboratory with suitable fluorescence equipment.

In the present state of knowledge of the treponematoses, this technique would seen to be thep most accurate means of diagnosing primary syphilis because it permits the specific identification of Treponema pallidum in chancre exudate. It has the advantage over the dark-ground method that: fixed films can be sent to the laboratory.

A fluorescent technique for demonstrating treponemes in fixed films made from suspected chancres was described by Garner and Robson in 1968. It was emphasized that this was not a specific technique for demonstrating Treponema pallidum in exudate from chancres. It merely revealed, as does the dark-ground method, the presence of treponemes morphologically indistinguishable from Treponema pallidum. The technique was felt to be of advantage to the medical practitioner who had no facilities for dark-ground examination in the surgery. It enabled him to prepare a slide from a suspected chancre, fix it, and send it to the laboratory for examination (Garner, 1967).

It has been shown by many workers that the treponemes all share a common antigen, as well as having specific antigens. Treponemes include the pathogenic treponemes-pallidum, pertenue, and carateum-and the non-pathogenic saprophytic genital and the mouth treponemes.

Eagle and Germuth in 1948 showed that the Reiter treponeme had the same antigenic structure as two mouth treponemes.

Deacon and Hunter in 1962 reported that the nonspecific reactions encountered in the fluorescent treponemal antibody test were due to group or common treponemal antibodies. They carried out Received for publication 3 November 1967. experiments which showed that the removal of these antibodies by absorption with Reiter treponemeso resulted in specific staining of the Nichols strain of Treponema pallidum.

Immunological studies of six genital treponemes Reiter, phagedenis, refringens, minutum, calligyra and pallidum - were carried out by Dupouey in 1963. Using sera from syphilitic patients on all six̧ organisms, he found only one common antigen:The common antigen shared between the Reite? treponeme and Treponema pallidum is the proteing antigen which detects the common group antibody

Kellogg and Deacon in 1964 used a rapid immunoo fluorescent staining technique for identifying treponemes. They used fluorescein-labelled $T:$ pallidum antiserum, both absorbed and unabsorbeo by Reiter treponemes. The treponemes they studieds were $T$. pallidum, pertenue, Reiter, $B$. vincentii, and $T$. microdentium. The unabsorbed $T$. pallidum conjugate showed varying degrees of fluroescence with all but $T$. microdentium whereas the absorbed conjugate showed fluorescence with only $T$. pallidum and $T$. pertenue. They also demonstrated that? $T$. pallidum in smears from true chancres gave brilliant, clear-cut results with the rapid immunofluorescent technique, whereas treponemes in smears from non-syphilitic lesions, and presumed to bed other than $T$. pallidum, did not show any fluorescence $\frac{\varrho}{\sigma}$ 
This technique has the disadvantage that it can only be performed in a specialized laboratory which has facilities for producing $T$. pallidum antiserum.

Fribourg-Blanc and Niel in 1967, using an immunofluorescent technique, showed that by the use of a suitable suspension of ultrasonicated Reiter treponemes they were able to absorb completely non-specific antibodies to $T$. pallidum from syphilitic sera, at the same time leaving the specific antibodies free to fix themselves normally to the treponemal antigen.

From all this it can be seen that by using a syphilitic serum from which the group antibody has been absorbed by Reiter treponemes, leaving only the specific antibody, it should be possible to indentify $T$. pallidum specifically by a fluorescent technique. This principle was used in the fluorescent treponemal antibody absorption test of Hunter, Deacon, and Meyer in 1964.

\section{METHOD}

A method for making and fixing slides of chancre exudate suitable for use in this test has already been described (Garner, 1967).

The immunofluorescence test technique was similar to that described by Garner and Robson in 1968, with the exception of the selection and treatment of the serum used. The serum selected for use in the absorption technique was a known syphilitic serum which has shown ++++ fluorescence with the fluorescent treponemal antibody absorption test. This serum was inactivated at $56^{\circ} \mathrm{C}$ for 30 minutes and then diluted 1 in 5 in Sorbent ${ }^{1}$. It was used within $\mathbf{3 0}$ minutes of dilution as recommended in the U.S. Venereal Disease Research Laboratory's provisional technique for the fluorescent treponemal antibody-absorption test dated 20 September 1965.

If a serum showing less than ++++ fluorescence in the fluorescent treponemal antibody-absorption test is selected the treponemes will show correspondingly less fluorescence and so be more difficult to find. Thus

${ }^{1}$ Sorbent, which is available commercially from Difco, Sylvana Company and the Baltimore Biological Laboratory, is the name given to an extract of Reiter treponemes which will remove the group antibody from syphilitic serum and leave only the specific antibody. This specific antibody will then couple with specific treponenes, ie, Treponema pallidum, if present on the slide.
Treponema pallidum, if present, with show ++++ bright apple green fluorescence.

\section{COMMENT}

All the reagents used in the test are available commercially, so this test can be performed in any laboratory which has a suitable fluorescence microscope.

A number of films of exudate containing a variety of genital treponemes, identified as other than $T$. pallidum on dark-ground examination, were examined. None of these showed any fluorescence when tested using the technique described.

Similarly, films of mouth treponemes were examined and showed no fluorescence.

This test will not distinguish between the pathogenic treponemes, ie, $T$. pallidum, pertenue, and carateum. However, the latter two do not give rise to genital sores. It distinguishes between the saprophytic non-pathogenic genital treponemes and the mouth treponemes on the one hand, and the pathogenic treponemes on the other.

We wish to thank Dr H. C. Johnston, Director, Division of Epidemiology, New South Wales Department of Public Health, for supplying the films of suspected chancre exudate used in this study.

This paper is published with the approval of the Director-General of Public Health, New South Wales.

\section{REFERENCES}

Deacon, W. E., and Hunter, E. F. (1962). Proc. Soc. exp. Biol. (N. Y.), 110, 352.

Dupouey, P. (1963). Ann. Inst. Pasteur, 105, 725.

- (1963). Ibid., 105, 949.

Eagle, H., and Germuth, F. G., Jr (1948). J. Immunol., 60, 223.

Fribourg-Blanc, A., and Niel, G. (1967). L'Immuno Fluorescence Appliquée au Diagnostic Sérologique de la Syphilis. Techique et Resultats de 1, Adsorption des Anticorps - Non Specifiques par L'Ultra-Sonnat de Treponeme de Reiter. WHO/VDT/ RES/67, 115.

Garner, M. F. (1967). Med. J. Aust., 2, 199

- , and Robson, J. H. (1968). J. clin. Path., 21, 108

Hunter, E. F., Deacon, W. E., and Meyer, P. E. (1964). Publ. Hlth Rep. (Wash.), 79, 410.

Kellogg, D. S., Jr, and Deacon, W. E. (1964). Proc. Soc. exp. Biol. (N.Y.), 115, 963 .

U.S. Public Health Service (1965). Provisional Technique for the Fluorescent Treponemal Antibody-Absorption (FTA-ABS) Test. U.S. P.H.S. Sept. 20, 1965. 